\title{
Vida e Encarnação no ser humano, em Cristo e na pintura de Kandinsky. Leitura de Michel Henry*
}

\section{Etienne Alfred Higuet ${ }^{* *}$}

\section{Resumo}

O meu objetivo neste ensaio é mostrar como a pintura de Wassily Kandinsky é uma verdadeira celebração da vida espiritual ou religiosa. Para alcançar esse fim, recorro à obra de Michel Henry Voir l'invisible (Ver o invisível), que comenta os estudos teóricos e as obras picturais de Kandinsky. Por sua vez, o estudo fenomenológico da vida na arte do pintor expressionista abstrato encontra os seus fundamentos na fenomenologia da vida e da carne, que Michel Henry desenvolve no seu livro Incarnation. Une philosophie de la chair (Encarnação. Uma filosofia da carne), no qual ele propõe uma filosofia do cristianismo, cujo centro é a ideia de encarnação do Verbo de Deus na carne humana, segundo o prólogo do Evangelho de João.

Palavras-chave: Fenomenologia, vida, carne, encarnação, expressionismo abstrato, Kandinsky.

* Michel Henry (1922-2002). Filósofo francês, ele dedicou o essencial das suas pesquisas aos fundamentos da fenomenologia, encontrados no fenômeno originário da vida. Está presente no coração do seu pensamento "o inicial aparecer a si do aparecer, o invisível vir a si da vida", ou a "imediação patética na qual a vida experimenta a si mesma". Isso o levou a descrições fenomenológicas da corporeidade, do agir e da arte. Criticando a fenomenologia clássica de Husserl e Heidegger, ele propõe a superação de uma fenomenologia intencional centrada na exterioridade do mundo. A partir do começo dos anos 1990, ele se interessou cada vez mais pelos textos fundadores do cristianismo e pela figura do Cristo. As principais obras dele constam da bibliografia final do presente ensaio.

** Graduado em filosofia e teologia. Doutor em Ciências teológicas e religiosas, pela Universidade Católica de Louvain, Bélgica. Professor aposentado do Programa de Pósgraduação em Ciências da Religião da Universidade Metodista de São Paulo. Última filiação na Universidade Federal de Juiz de Fora, MG. E.mail: etienne.higuet@gmail.com. Lattes: http://lattes.cnpq.br/5600938581821983. 


\section{Life and Incarnation in human being, in Christ and in Kandinsky's Painting. Reading by Michel Henry}

\section{Abstract}

My aim in this essay is to show how Wassily Kandinsky's painting is a true celebration of spiritual or religious life. To achieve this end, I turn to the work of Michel Henry Voir l'invisible (Seeing the invisible), which comments on the theoretical studies and pictorial works of Kandinsky. In turn, the phenomenological study of life in the art of the abstract expressionist painter finds its foundations in the phenomenology of life and flesh, which Michel Henry develops in his book Incarnation. Une philosophie de la chair (Incarnation. A philosophy of the flesh), in which he proposes a philosophy of Christianity, the center of which is the idea of the incarnation of the Word of God in the human flesh, according to the prologue of the Gospel of John.

Keywords: Phenomenology, life, flesh, incarnation, abstract expressionism, Kandinsky.

\section{La vida y la encarnación en el ser humano, Cristo y la pintura de Kandinsky. Lectura de Michel Henry}

\section{Resúmen}

Mi objetivo en este ensayo es mostrar cómo la pintura de Wassily Kandinsky es una verdadera celebración de la vida espiritual o religiosa. Para lograr este fin, me dirijo a la obra de Michel Henry Voir l'invisible (Ver lo invisible), que comenta los estudios teóricos y las obras pictóricas de Kandinsky. A su vez, el estudio fenomenológico de la vida en el arte del pintor expresionista abstracto encuentra sus fundamentos en la fenomenología de la vida y la carne, que Michel Henry desarrolla en su libro Incarnation. Une philosophie de la chair (Encarnación. Una filosofía de la carne), en la que propone una filosofía del cristianismo, cuyo centro es la idea de la encarnación de la Palabra de Dios en la carne humana, según el prólogo del Evangelio de Juan.

Palabras clave: Fenomenología, vida, carne, encarnación, expresionismo abstracto, Kandinsky.

\section{Introdução}

Ao pesquisar nas obras de Paul Tillich sobre o expressionismo, me deparei com algumas anotações sobre o expressionismo abstrato, sobre o seu fundador: Wassily Kandinsky, e sobre os expressionistas abstratos norte-americanos dos anos 1950, como Mark Rothko, Barnett Newman e Hans Hofmann. Por exemplo, ele escreve, em Religious Dimensions of Contemporary Art: "A tela Magenta and Blue, de Hans Hofmann, um exemplo do expressionismo abstrato, mostra apenas os elementos das coisas, não as próprias coisas. Cores, linhas, círculos se unem em formas que estão potencialmente presentes nas coisas, mas que a natureza nunca teve a 
oportunidade de criar. Através do artista, o fundamento criador do ser cria formas que não existem na natureza, mas que revelam o poder do ser (TILLICH, 1987, p. 180)". A mesma coisa poderia ter sido dita de Kandinsky.

Reencontrei Kandinsky ao ler a obra Philosophie des images, de JeanJacques Wunenburger, que foi a principal fonte de inspiração do meu primeiro estudo teórico sobre a cultura visual e a interpretação das imagens religiosas (HIGUET, 2012, p. 69-106). Pela mesma ocasião, tive acesso à obra de Michel Henry, Voir l'invisible. Por exemplo, "para M. Henry, a crítica da representação imagética, o desaparecimento da figura se impõem precisamente quando se procura apreender imediatamente o Ser, revela-lo na passividade primeira do afeto (WUNENBURGER, 1997, p. 181)". Ao contrário das representações figurativas, a arte não figurativa - por exemplo, em Kandinsky -, nos providencia a experiência do Ser, ao nos fazer experimentar diretamente a Vida, pois nos expõe ao pathos imediato do que é, à pulsão do Ser em nós, ao paroxismo da vida que só se manifesta no êxtase.

Em Voir l'invisible: sur Kandinsky (HENRY, 1988), Michel Henry descobre na pintura e nas obras teóricas de Kandinsky, especialmente em Do Espiritual na Arte (KANDINSKY, 2000) a presença de uma autêntica fenomenologia da vida invisível, que o nosso filósofo se esforça por desvendar. Dedicada à dimensão espiritual ou religiosa da arte, essa pequena obra me pareceu antecipar a reflexão que Michel Henry desenvolveu a partir do início dos anos 1990, quando ele passou a se interessar cada vez mais pelos textos fundadores do cristianismo e pela figura do Cristo, em C'est moi la vérité (1996), Incarnation (2000) e o seu livro-testamento Paroles du Christ (2002).

Em particular, Incarnation, une philosophie de la chair me pareceu oferecer os fundamentos da fenomenologia da vida aplicada à arte espiritual de Kandinsky, pois encontramos nessa obra uma filosofia do cristianismo - em particular, do dogma da Encarnação - na qual a fenomenologia da vida se desenvolve em fenomenologia da carne e em fenomenologia da Encarnação.

A primeira parte do presente ensaio será então dedicada a uma leitura pessoal de Incarnation. Os seres humanos só podem fazer a experiência imediata do próprio corpo e sentir os outros corpos por serem "encarnados". A encarnação consiste no fato de ter uma carne, talvez até mais: de ser carne. Seres encarnados são seres que sofrem, que são atravessados pelo desejo e o medo, que sentem a série das impressões ligadas à carne. Através das impressões de dor e de prazer, cada um sabe, por um saber absoluto e ininterrupto, o que é sua carne. "Assim se enuncia uma definição do ser 
humano, inteiramente nova, tão desconhecida da Grécia que da modernidade: a definição de um ser humano invisivel e carnal, ao mesmo tempo - invisivel enquanto carnal (HENRY, 2000, p. 28-29)".

Como nós, o Cristo possuía um corpo real, uma carne real. Fazendose carne, o Verbo - a Palavra de Deus - se fez homem. Em consequência, a relação do ser humano com Deus não será colocada apenas na carne, mas dentro de uma única e mesma pessoa, isto é, o Cristo. Assim, a relação com Deus deverá passar "pela passibilidade, a fragilidade, a vulnerabilidade, a fome, a sede, os sofrimentos, a história terrível da paixão do Cristo - pela sua morte” (ID., p. 21).

Nos Pais da Igreja, o tornar-se-homem de Deus fundamenta o tornarse-Deus do ser humano. A salvação cristã consiste na deificação do ser humano. O homem cristão poderá identificar-se a Deus ao identificar-se à carne do Verbo encarnado. O que pressupõe que "a unidade do Verbo e da carne seja possível e se realize em primeiro lugar lá onde o Verbo se fez carne, isto é, no Cristo" (ID., p. 23). Pela Encarnação do Verbo, a própria carne torna-se revelação de Deus.

A partir daí, desenvolve-se uma nova inteligibilidade, alheia ao logos grego, uma arqui-inteligibildade que revela realidades invisíveis neste mundo, inacessíveis ao pensamento: a Vida, na qual ela consiste; o Verbo de Vida, na qual ela se realiza; a carne, enfim, na qual o Verbo de Vida se torna idêntico a cada um dos vivos que somos nós os seres humanos. A arqui-inteligibilidade diz respeito à realidade absoluta, que a religião chama de Deus - este Deus que, segundo João, é Vida.

Haverá uma ciência da revelação do Verbo na carne? Michel Henry pretende que sim: trata-se da fenomenologia. Mas a fenomenologia até agora (Heidegger) continua dependente do pensamento grego, do campo do pensamento. Por isso, será preciso operar a reviravolta da fenomenologia, isto é, substituir a uma fenomenologia do mundo ou do Ser uma fenomenologia da Vida. Em consequência, o autor propõe um percurso em três etapas: a virada da fenomenologia, a fenomenologia da carne e a fenomenologia da Encarnação ou a salvação no sentido cristão.

A segunda parte, mais breve, acompanhará a reflexão de Michel Henry tentando apreender fenomenologicamente a Vida que pulsa na "carne" da pintura abstrata de Wassily Kandinsky. É que a pintura de Kandinsky expressa a vida que se experimenta a si mesma no seu pathos interior e imediato, com a missão de sustentar e levar ao paroxismo da vida a pulsão do Ser em nós. 


\subsection{A virada da fenomenologia}

Para poder elaborar uma fenomenologia da vida, uma fenomenologia da carne e uma fenomenologia da encarnação, Michel Henry percebe a necessidade de rever a concepção da fenomenologia e de operar uma virada completa da fenomenologia clássica, assim como ela é desenvolvida nas obras de Husserl e Heidegger.

$\mathrm{O}$ verdadeiro objeto da fenomenologia não é exatamente o fenômeno, o que aparece, mas o ato de aparecer, que é a essência do fenômeno. As palavras-chave da fenomenologia são, na forma substantiva, doação, mostração, fenomenalização, ${ }^{1}$ desvendamento, descobrimento, aparição, manifestação, revelação. Essas palavras são também, em grande medida, as palavras-chave da religião e da teologia. O que nos leva a outra palavra, que governou o pensamento filosófico desde a Grécia: a verdade. O verdadeiro deve se mostrar, mas, para isso, precisa de um poder de desvendamento: o puro ato do aparecer, o que Heidegger chama de "o fenômeno mais originário da verdade" (HENRY, 2000, p. 38). Isso tem consequências para a compreensão da vinda e da aparição do Verbo neste mundo: como compreendê-la se o modo de aparecer do mundo não foi reconhecido previamente e descrito com todo rigor?

Ora, a fenomenologia histórica não fornece uma resposta satisfatória a respeito da substância fenomenológica pura do aparecer, por causa da indeterminação dos seus pressupostos fenomenológicos. Os dois princípios de Husserl: a identidade do aparecer e do ser e a volta às coisas mesmas, sofrem dessa indeterminação do aparecer, o que impede uma determinação clara do ser e das coisas mesmas, ou dos fenômenos reduzidos ao seu conteúdo fenomenológico efetivo. Falta dizer em que consiste o poder do aparecer, pressuposto por todo aparecer.

O preconceito oculto dos pressupostos da fenomenologia clássica é a redução nefasta de todo "aparecer" ao aparecer do mundo. É uma consequência da compreensão da estrutura da consciência como intencionalidade, a qual fundamenta o poder fenomenológico da intuição. Assim, a revelação operada pela intencionalidade consiste em fazer ver o que está na exterioridade. A revelação é a revelação do objeto, do que está colocado à distância. Há uma cisão nítida entre a realidade substancial da consciência e o que está colocado fora dela, o que lhe é "transcendente". É

Estou transpondo diretamente em português os neologismos criados pelo autor para expressar o próprio pensamento. 
a intencionalidade que revela toda coisa - nisso reside o seu poder - mas fica a pergunta: como a intencionalidade se revela a si mesma? Quem já viu a própria visão? Não haveria um modo de revelação diferente do "fazer ver" da intencionalidade, uma revelação cuja fenomenalidade não seria mais a exterioridade do mundo?

Em Heidegger, o aparecer será pensado como o tempo, o qual será conceitualizado como "temporalização da temporalidade" (ID., p. 57). "As três intencionalidades husserlianas constitutivas da consciência interna do tempo - pro-tensão do futuro, consciência do agora, retenção do passado - se tornaram três Ek-stases, os do por-vir, do presente e do passado. A passagem contínua de um ekstase a outro configura o horizonte de visibilidade em que consiste o aparecer do mundo para nós. Assim, mundo e tempo aparecem na exterioridade, no "fora de si". Tudo o que se mostra no mundo se mostra na exterioridade, na alteridade primordial ou Diferença entre o que aparece e o horizonte no qual se mostra, entre o que aparece e o próprio aparecer. A consequência é que o ser humano se torna um ser do mundo, abandonado no mundo, na indiferença do aparecer do mundo. Além disso, o aparecer do mundo é incapaz de conferir a existência ao que se revela nele, há exclusão recíproca do ser e do aparecer. "Se o aparecer do mundo é, por princípio, incapaz de fundamentar a realidade do objeto ao qual ele dá de aparecer, de onde vem essa realidade?" (ID., p. 64)

Do mesmo modo, a linguagem, que repete a estrutura do aparecer do mundo, remete a um referente exterior a ela, cuja realidade ela não pode fundamentar. O aparecer, do qual a linguagem toma emprestada a sua capacidade de fazer ver, des-realiza, no princípio, toda realidade que se mostra nele. Assim como apareceu em Kant, a formação fenomenológica do mundo - a representação - é, para sempre, incapaz de fundamentar por si mesma a realidade que constitui o conteúdo concreto deste mundo.

Por isso, Kant precisou recorrer à sensação. Do mesmo modo, em Husserl, a intencionalidade - a consciência é sempre consciência de algo não é doação imediata da coisa, pois só alcança a significação, que é uma irrealidade, um objeto-de-pensamento. Assim, a realidade da cor se mantém apenas lá onde é ressentida em nós, na cor "impressional” ou sensual. O conteúdo real do mundo sensível não corresponde à sua estrutura fenomenológica, mas apenas à impressão (Empfindung), elemento sensual puro alheio à intencionalidade. Todos os modos da consciência acabam sendo identificados à impressão, inclusive a própria intencionalidade. 
Por outro lado, a impressão não se revela mais nela mesma, ela está sendo arrancada do seu sítio originário para ser jogada no objeto, enquanto qualidade do objeto. Nasce a grande ilusão do "mundo sensível", constituído por todas as qualidades sensíveis dos objetos. A revelação própria da impressão, que veio fora de si no fluxo temporal, é ocultada e a impressão é simplesmente destruída, por ser objeto de uma intencionalidade que, consciência de um presente ilusório, visa um passado irremediavelmente perdido. Não há mais lugar para a revelação da carne, já que ela não pode se mostrar no aparecer do mundo. Sua natureza seria falsificada, confundida com a natureza do corpo. Ora, segundo João, os seres humanos são Filhos de Deus, que só podem ser reconhecidos na carne, isto é, a partir de uma inteligibilidade outra que a inteligibilidade do mundo, pois nenhuma carne pode aparecer no aparecer do mundo.

De onde vem, então, a impressão originária? Originário designa "o que vem a si antes de toda intencionalidade e independentemente dela, antes do espaço de um olhar, antes do 'fora de si' do qual a intencionalidade é apenas um nome. O que vem no começo, antes do mundo, fora do mundo, alheio a todo 'mundo' concebível, a-cósmico (ID., p. 82)". A origem da impressão é o seu próprio aparecer, não é o aparecer do mundo, mas o aparecer da Vida, que é a própria Vida na sua fenomenalização originária. O seu protótipo está no sofrimento, na dor pura que não é uma dor "física" ligada ao corpo, mas um sofrimento sem tempo, sem horizonte, sem esperança, ocupando o lugar todo, imerso em si mesmo, amassado pelo próprio peso, incapaz de sair de si mesmo, de se distanciar de si mesmo. O sofrimento só é afetado por ele mesmo, é uma auto-afeição no sentido radical, é, ao mesmo tempo, o afetante e o afetado, o que faz sofrer e o que sofre, indistintamente.

Trata-se então de aceder à essência mais originária da passividade, que não encontre a sua condição última na intencionalidade, pois há uma passividade não ek-stática como fundamento de toda passividade ek-stática. A vinda a si que antecede toda impressão concebível é a vinda a si da Vida. A Vida é uma auto-revelação no sentido radical. Ela é uma Afetividade originária e pura, que se experimenta a si mesma num pathos. É transcendental porque condição de possibilidade do se experimentar a si mesma sem distância na passividade insuperável de uma paixão. "A afetividade originária é a matéria fenomenológica da auto-revelação que constitui a essência da vida (ID., p. 90)". É uma matéria impressional, uma auto-impressionalidade viva. Em outras palavras, é uma carne. 
Contrariamente à concepção husserliana do fluxo temporal irremediável das impressões, estamos vivendo num eterno presente, o eterno presente vivo da vida, a Morada da Vida na qual tudo é vida, fora da qual nenhuma vida é possível. De fato, não podemos nos manter em nenhum futuro e em nenhum passado, em nenhum mundo. É na vida que nós nos mantemos, é ela que persiste e que subsiste na mudança incessante da impressão, a vida na auto-afeição patética do seu viver - no seu Presente vivo.

Michel Henry vai encontrar no cogito de Descartes um pressentimento das determinações fenomenológicas essenciais implicadas pelo aparecer originário. No parágrafo 26 das Paixões da alma, Descartes parte da desqualificação prévia e global do ver - e consequentemente do mundo - que encontra a sua figura no sonho. Na ausência de "mundo", o último fundamento aparece na tristeza ou em qualquer outro sentimento experimentado no sonho. Embora tudo seja ilusão no sonho, a tristeza experimentada é verdadeira, ela existe absolutamente e assim como eu a experimento. Ela vai aparecer como Afetividade transcendental, como a Vida da qual fala João, uma vida que se traz a si mesma em si e que João chama de Deus.

Descartes chama essa vida de cogitatio. Não se trata, de modo algum, de pensamento. "É a própria cogitatio - na qual não há nem distância, nem ver, nem evidência possível - que se traz a si mesma em si, e ela o faz em razão da sua própria essência, enquanto esta reside na auto-revelação (ID., p. 98)". Também na "Segunda Meditação", o ver se revela certeiro, não mais na sua operação na luz do mundo, mas enquanto cogitatio, como Verdade da Vida, no aparecer em que o ver se revela a si mesmo. Esse ver difere por princípio do aparecer em que o ver vê tudo o que ele vê, e que é duvidoso. ${ }^{2}$

Se o verdadeiro objeto da fenomenologia não consiste nos objetos, mas no seu modo de doação, no seu aparecer, ela não pode se contentar - como Husserl - com a existência de fato de uma intuição da essência da vida e das suas estruturas típicas (a intencionalidade, a forma do fluxo, as formas de essências de cada tipo de intencionalidade, como percepção e imaginação), sem perguntar como tal intuição é possível. É só tomando a auto-revelação originária da vida como fundamento do método fenomenológico que se poderá responder ao problema filosófico geral que diz respeito à possibilidade

No par. 12, Michel Henry mostra a interpretação equivocada do cogito cartesiano por Husserl, na medida em que reconduz a cogitatio ao pensamento intencional e se coloca na impossibilidade de aceder à vida real e à impressão (p. 103-111). 
de pensar a vida e de pensar a nossa carne, que não aparece em nenhum lugar, senão na vida. Não há nenhum acesso possível à vida fora dela mesma, a partir de qualquer objeto intencional ou do mundo. Só há acesso à vida na própria vida.

É que, desde sempre, "no começo" (In principio Jo 1,1), uma Vida absoluta - a Vida única e absoluta de Deus - veio a si, ao experimentar-se a si mesma na prova patética do Primeiro Si vivo - que é o seu Verbo - e que, nessa vinda a si da Vida absoluta, viemos a nós mesmos, de tal modo que somos viventes. Assim, teremos acesso à vida tendo acesso a nós mesmos, isto é, ao processo da nossa geração no seio do processo eterno no qual a Vida absoluta vem a si. Enquanto viventes, somos seres do invisível. Somos inteligíveis apenas no invisível, a partir dele, e não no mundo, nas suas estruturas fenomenológicas das quais a vida escapa. Um corpo humano não pode ser outra coisa que uma carne viva, uma carne invisível, inteligível no invisível da vida e apenas a partir dela.

Antes da visão das coisas e de seus arquétipos, antes do aparecer do mundo, antes da sua criação, há uma inteligibilidade de outra ordem, uma arqui-inteligibilidade que é a inteligibilidade da Vida - do Invisível. "É o processo de auto-geração da vida enquanto a sua auto-revelação no Verbo que constitui a Arqui-inteligibilidade da qual fala João (ID., p.125).” Isto é, a Vida acede a si-mesma imediatamente, sem pensamento, sem intencionalidade e sem conceitos.

Estamos em presença da virada da fenomenologia: "não é o pensamento que nos faz aceder à vida, é a vida que permite ao pensamento de aceder a si, de se experimentar a si mesmo e, enfim, de ser o que ele é cada vez: a auto-revelação de uma cogitatio (ID., p.129)". A fenomenologia se dedicará, doravante, à exploração do invisível que determina o nosso ser profundo e à compreensão da relação que mantém entre si os dois modos decisivos segundo os quais a fenomenalidade se atualiza: o visível e o invisível, o ver intencional e o que permite a esse ver advir a si na ausência de todo ver: a sua auto-doação patética na Vida absoluta. Assim, a arqui-inteligibilidade é anterior a toda inteligibilade concebível e, além disso, ela a funda e a torna possível. A partir dela poderemos formar da vida, para fins de estudo, uma re-presentação, uma imagem, uma cópia, algum equivalente objetivo, mas vazio, frágil, tão incapaz de viver quanto de subsistir por si mesmo. Uma fenomenologia da carne é doravante possível. 


\subsection{Fenomenologia da carne}

Podemos tratar da questão do corpo e da carne numa perspectiva fenomenológica, de dois modos diferentes: segundo o aparecer do corpo no mundo; segundo o aparecer da carne na vida. O corpo é um objeto do mundo, do qual recebe a sua determinação fenomenológica e ontológica. Fenomenologicamente, todos os corpos que se manifestam no aparecer do mundo aparecem segundo as intuições fenomenológicas puras do espaço e do tempo e as categorias do entendimento como modos de re-presentação. Contudo, a estrutura a priori do corpo mundano não diz nada ainda da sua existência, o que exige a intervenção da sensação. Todos os corpos que "povoam" o universo, inclusive o nosso, são corpos sensíveis: possuem cores, sabores, sonoridade e muitas propriedades táteis. Mas o mundo sensível, constituído por todas as qualidades sensíveis de todos os corpos, não deriva do aparecer do mundo, mas da sensação, isto é, da vida. Para tratar dele, somos remetidos a uma fenomenologia da vida.

Ao aparecer do mundo, incapaz de fundamentar o próprio conteúdo, opõe-se o corpo sensível. É um corpo sentido, que é também um objeto do mundo. São numerosas as concepções que consideram o corpo como um objeto sensível mundano. Mas um corpo mundano estendido, reduzido à sua exterioridade, não possui, como tal, nenhuma matéria impressional, nenhuma qualidade sensível. Então precisamos nos render à evidência: todo corpo sentido pressupõe outro corpo que o sente. Todo corpo visto pressupõe um poder de visão e a operação deste poder. A mesma coisa vale para os outros sentidos. Somos remetidos a um corpo transcendental portador dos poderes fundamentais de ver, sentir, tocar, ouvir, mover e se mover, e definido por eles. "Transcendental" porque condição de possibilidade do corpo sentido, mundano. É um corpo sentente e sentido ao mesmo tempo, um corpo-sujeito, oposto a um corpo-objeto do qual é a condição. "O corpo transcendental, que nos abre ao corpo sentido, seja ele o nosso ou o das coisas, repousa numa corporeidade muito mais originária, transcendente num sentido último, não intencional, não sensível, cuja essência é a vida (ID., p.168-169)".

A revelação da vida é uma auto-revelação, o "se experimentar a si mesmo" originário e puro, no qual o que experimenta e o que é experimentado é uma coisa só. Isso é possível porque a vida é fenomenologicamente um pathos, cuja matéria fenomenológica é a afetividade pura, a impressionalidade pura, a auto-afeição radicalmente imanente que é a nossa carne. A interioridade recíproca da Carne e da Vida só diz respeito a uma vida como a nossa porque, 
antes do tempo, antes de todo mundo concebível, ela se estabeleceu na Vida absoluta como o modo fenomenológico segundo o qual essa Vida vem eternamente em si no Arqui-Pathos da sua Arqui-Carne.

Somos remetidos à compreensão de Deus como Vida absoluta. Enquanto tal, Deus é caracterizado pela possibilidade a priori de se experimentar a si mesmo no Arqui-Pathos de uma Arqui-Carne, isto é, pela Arqui-passibilidade. O Deus cristão não é impassível como o deus grego. É um Deus que compartilha conosco o sofrimento, a alegria de viver e o amor. Por isso, no cristianismo, transcendência designa a imanência da Vida em todo vivente.

"A geração do vivente na Vida é a geração do nosso Si transcendental no Arqui-Si da Vida absoluta - no seu Verbo - e, identicamente, a geração da nossa própria carne na Arqui-Carne deste Verbo (ID., p.177)”. Não há nenhum Si, nenhum eu sem uma carne, mas não há nenhuma carne que não carregue nela um Si. Não há nenhuma carne que não seja a carne de um Si particular. Ego e carne são um, pois procedem da Vida, sendo apenas as modalidades fenomenológicas originárias e essenciais nas quais a vida vem a si, isto é, nasce. Nascer significa vir numa carne, na Arqui-Carne da Vida. Assim, uma fenomenologia da carne remeterá necessariamente a uma fenomenologia da Encarnação.

A fenomenologia da carne foi elaborada pelos Pais da Igreja Tertuliano e Irineu em vista de aplica-la à carne do Cristo, semelhante à carne de todo ser humano, uma carne cujo nascimento está necessariamente ligado à morte. Pois o Cristo nasceu para cumprir a missão de morrer pela salvação do mundo. O que está em questão, contra a heresia, é a realidade da encarnação do Cristo e, consequentemente, da carne que ele assumiu. Se a carne dele não fosse real, ele não teria nada sofrido nem suportado e não nos salvaria. Sempre e em toda parte, os Pais da Igreja afirmam categoricamente a realidade da carne do Cristo. E eles o fazem, no primeiro momento, no horizonte fenomenológico e ontológico do aparecer do mundo, com toda a sua concretude terrena.

Vai acontecer, então, na problemática dos Pais, uma virada decisiva, pela qual as determinações objetivas do corpo material que se mostram a nós no mundo deixam o lugar para as determinações impressionais e afetivas que se revelam no pathos da vida, e que constituem a matéria fenomenológica da qual a carne é feita. Trata-se dos sofrimentos, pelos quais Ireneu e Tertuliano vão definir a realidade da carne do Cristo, assim como a realidade da nossa 
própria carne, pois é no sofrimento que a vida alcança o seu próprio Fundo. Assim vai operar-se, na problemática cristã, a dissociação irreversível do corpo e da carne e a sua impossível confusão. A conexão entre realidade, carne e sofrimento remete imediatamente, em Tertuliano e nos outros Pais, à Paixão do Cristo. "É da realidade de uma carne definida pelo seu sofrimento que a Encarnação do Cristo e, de modo exemplar, sua paixão, recebe agora sua realidade e sua verdade (ID., p.188)".

A vida da qual trata Irineu não é mais o bios dos gregos, é a vida fenomenológica transcendental, a auto-revelação patética da qual a carne recebe o seu pathos, a sua realidade enquanto realidade fenomenológica pura. É que precisa pensar a Encarnação do Verbo na sua formulação joanina, isto é, a correlação originária entre a carne, a vinda na carne e a auto-revelação da Vida absoluta no seu Verbo. Irineu derruba a gnose, que queria mitigar a realidade da carne, em duas proposições fundamentais, que o autor traz numa formulação atualizada: "longe da vida ser incapaz de assumir a carne, ela é a condição de possibilidade da mesma; longe de ser incapaz de receber a vida, a carne é a efetivação fenomenológica da mesma (ID., p.191)". Pois a carne é capaz de receber e de conter a potência de Deus.

Se vivemos presentemente, se o nosso corpo todo participa da vida, como poderíamos dizer que a carne é incapaz de participar da vida, ao passo que reconhecemos possuir presentemente a vida? Todo poder, como o poderver ou o poder-tocar, diz respeito à imanência essencial da nossa corporeidade originária, que se realiza na Vida, do modo como a Vida vem pateticamente a si sob a forma de uma carne. A corporeidade, como o conjunto dos nossos poderes, só é possível na carne.

A imanência na minha carne de todos os seus poderes faz dela o lugar de uma memória originária, que tem como correlato a unidade imanente do mundo. A lembrança das coisas está ligada aos caminhos, aos esforços, aos movimentos que nos levaram até elas. É a memória dessas ações que contém o sentimento da potência de repeti-las. Enfim, "porque, na minha carne, sou a vida do meu corpo orgânico, sou também a vida do mundo. É nesse sentido originário, radical, que o mundo é o mundo-da-vida, uma Lebenswelt (ID., p. 216)".

\subsection{Fenomenologia da Encarnação: a salvação no sentido cristão.}

Embora a carne seja, no Novo Testamento, o lugar do pecado, é ao se fazer carne que o Verbo traz aos seres humanos a salvação. Assumindo 
uma carne semelhante à carne deles e identificando-se assim a eles, vai lhes permitir tornarem-se Deus como ele. Para entender como a carne pode ser, ao mesmo tempo, o lugar da perdição e o da salvação, vamos precisar de uma fenomenologia da Encarnação.

Todo poder da minha carne carrega o estigma de uma impotência radical, de um não-poder absoluto, pois ela não tira o seu poder de si mesma. Ela tampouco o recebe do mundo, mas da auto-doação da Vida absoluta, pela vinda originária da Vida na Ipseidade do primeiro Si. Paradoxalmente, este não-poder que carrega em si todo poder é a própria condição de possibilidade do poder (Cfr. 2 Cor 12, 10: "É quando sou fraco que sou forte"). Mas, se o ser humano não é o verdadeiro dono dos seus poderes, a própria carne na sua singularidade encontra-se excluída da possibilidade de constituir em si mesma e por si mesma uma existência efetiva e autônoma. Se o princípio de individuação é o mundo, a vida, que é alheia ao mundo e às suas categorias fenomenológicas, fica também alheia aos indivíduos. Por conseguinte, tornada impessoal e anónima, a vida encontra-se privada também da fenomenalidade, ela se realiza na inconsciência. O movimento da vida se reduz a uma força cega, a uma "pulsão".

Contudo, se a identificação cristã da Verdade à Vida designa a autorevelação da Vida (ou de Deus) na Ipseidade do Si originário, como modo fenomenológico da sua realização, o conceito de uma vida inconsciente, anónima e impessoal, apenas biológica, torna-se absurdo. Assim, todo indivíduo, dado a si na Ipseidade da Vida absoluta, encontra-se gerado como um Si real, como este Si singular que ele é para sempre. Essa geração do Si transcendental é identicamente a geração de uma carne auto- impressional que lhe pertence desde o princípio. É nela que reside a liberdade como poder originário, como "eu posso" consubstancial ao seu Si carnal e vivo. A vida individual é também sujeito de uma memória imemorial, que é a própria vida no seu pathos, a nossa carne. Assim, a nossa vida escapa do esquecimento na sua práxis mais elementar e mais cotidiana, em nossos gestos mais simples, mais habituais e mais humildes.

A vida escapa também do esquecimento pela angústia, tão essencial à vida quanto o sofrimento ou o prazer. $\mathrm{O}$ autor descreve a angústia a partir da análise da inocência em Kierkegaard. No seio da inocência, pathos situado na imanência radical da vida, se revela a nós na angústia uma possibilidade radical de poder. A inocência encontra-se submersa pela angústia secreta, própria ao campo do pathos, de uma "liberdade vertiginosa (ID., p. 276)". 
A angústia resulta da duplicidade do aparecer do ser humano: corpo objetivo e carne. "Enquanto percebo o meu próprio corpo no mundo, sou essa carne oculta, sentindo, se movendo e sofrendo, que confere ao meu corpo objetivo os caracteres que ele possui, para mim como para os outros (ID., 286)". Acompanhando Kierkegaard, o autor apresenta então, como aplicação, o caso exemplar da sexualidade, da relação erótica e do desejo, que provoca a reduplicação da angústia. Na realidade, é apenas um caso particular da relação absolutamente geral e essencial que relaciona, no princípio, Afetividade e Ação, isto é, a nossa própria carne. ${ }^{3}$

É que a vida é sem "porque". Ela não depende de nenhuma exterioridade para se manifestar ou simplesmente ser, nem para perguntar porque, em vista de que ela é a vida. Isso, porque ela carrega em si o seu princípio último de inteligibilidade e justificação, que está no fato de se experimentar a si mesma, na felicidade desta provação que é o seu gozo de si, que lhe diz que ela é boa. A rosa de Angelus Silesius, que é sem porque, é apenas o nome da vida. Todos os caracteres negativos do corpo humano desaparecem quando, vivido a partir de dentro, o corpo se revela a si mesmo como carne viva.

Desse modo, a vida remete a uma passividade originária, a uma contingência concretamente experimentada por cada um de nossos poderes na sua operação particular. É como si o aparecer do mundo desvendasse a contingência radical de uma diversidade de propriedades específicas (visão, audição, motricidade, atividade sexual etc.) já inscrita na carne. É preciso lembrar essa passividade radical para poder compreender a possibilidade para uma carne de constituir, segundo o ensino do cristianismo, a via da perdição e a via da salvação.

O livro de Gênese é a primeira exposição conhecida de uma teoria transcendental do ser humano, se entendermos por "transcendental" a possibilidade pura e a priori da existência de algo como o ser humano. Adão aparece como o arquétipo de todo ser humano concebível. A essência da qual o ser humano recebe a sua procedência é a essência da própria realidade, do absoluto que é a vida, isto é, de Deus. Em Gênese, o conceito de criação marca a priori a totalidade do ser por uma passividade radical definitiva. Somos passivos em relação com o mundo, tanto em relação com o seu horizonte ek-stático de visibilização quanto em relação com o conteúdo que se mostra neste horizonte. A passividade dessas duas relações reside na sensibilidade.

3 Essa parte consiste numa descrição fenomenológica minuciosa, cuja apresentação não poderia caber no quadro deste ensaio (p. 284-318). 
Mas esse conceito de criação é radicalmente questionado quando aparece que Deus criou o ser humano à sua imagem e semelhança. Semelhante a Deus, o ser humano não foi posto fora de Deus como imagem, pois o ser humano não é nada visível, por ser um Si transcendental vivo. O ser humano não foi criado, não veio no mundo, ele veio na Vida. É nisso que ele é semelhante a Deus. No Prólogo de João, que representa a unidade da visada transcendental das Escrituras, o ser humano é entendida a partir da ideia de geração, não de criação: a geração do ser humano no Verbo repete a geração do Verbo em Deus como a sua auto-revelação. Assim, o Verbo não vai se encarnar no mundo, mas numa carne, entre os seus, no meio daqueles que foram gerados nele e lhe pertencem desde sempre.

Não há mais passividade radical em relação ao mundo, mas em relação à Vida. Trata-se da Afetividade transcendental, heterogênea à sensibilidade. $\mathrm{Na}$ sua radicalidade, essa passividade remete à sua fonte oculta: a vinda da Vida absoluta no seu Verbo como condição do nosso nascimento transcendental, da nossa condição de Filho. É essa passividade radical que abre, segundo o cristianismo, a via da salvação.

A Encarnação do Verbo em nossa carne finita deve nos permitir reencontrar a nossa relação inicial com Deus, e bem mais, serem feitos Deus. Isso, porque há uma afinidade essencial entre a criação originária do ser humano e a Encarnação do Verbo. É o que nos permite superar, conforme Irineu, a "apostasia do pecado", que nos tinha alienados da nossa natureza. Eis o paradoxo cristão: o lugar da salvação é o mesmo que o lugar do pecado: a nossa carne finita. Porque ela constitui o lugar de toda ação real, a carne define também o lugar da salvação. Pois esta consiste, não num dizer, mas num fazer (cf. Mt 7, 21: "Não basta dizer: Senhor! Senhor!, para entrar no reino dos céus, mas é preciso fazer a vontade do meu Pai, que está nos céus"). Ao se encarnar, o Verbo assumiu o pecado e a morte inscritos na nossa carne finita e os destruiu ao morrer na Cruz.

Segundo João, um único e mesmo princípio de inteligibilidade, ou, antes, de Arqui-inteligibilidade, atravessa o Verbo e os seres humanos para uni-los no Cristo. Trata-se da auto-revelação da Vida absoluta. Estamos então em presença do corpo místico do Cristo. A unidade de todos os seres humanos em Cristo constitui a primeira condição da salvação, já que "é apenas se todos os seres humanos estão no Cristo, um só com ele, se eles são o próprio Cristo, que, ao santificar-se a si mesmo, o Cristo os santifica todos nele, os salvando pelo mesmo ato (ID., p. 338-339)". Fenomenologicamente, o 
corpo místico só é possível se os seres humanos podem chegar a ser um, sem que seja perdida a individualidade de cada um e que a experiência continue sendo a experiência do outro.

Como fica a experiência de outrem na fenomenologia da vida? A experiência que um si faz de outro si, de aceder à própria vida do outro, é antes de tudo afetiva, por isso, a carne desempenha nela, como na relação amorosa, um papel essencial. Mas a carne depende do que vem antes dela: sua própria vinda a si, sua encarnação - a qual só advém na vinda a si da Vida absoluta. A Vida absoluta é assim a comum possibilidade transcendental da relação de todo si com outro. Desse modo, nasce e toma forma toda comunidade concebível, cujo conteúdo é a vida transcendental, isto é, tudo que pertence à Vida e encontra nela a sua possibilidade: sofrimento, alegria, deseja e amor, os quais possuem uma potência de reunião muito maior que a "razão".

Em consequência, toda comunidade é essencialmente religiosa, invisível, alheia ao mundo e a suas categorias fenomenológicas, ao espaço e ao tempo. Assim, a realidade da comunidade abre o campo de relações paradoxais que constituem o núcleo do cristianismo, por exemplo, o estabelecimento de uma relação real entre Si transcendentais que nunca se encontraram e pertencem a épocas diferentes, o que a tradição chama de a "comunhão dos santos". Na relação de interioridade fenomenológica recíproca entre a Vida absoluta e o Primeiro Vivente, cada um se ama num "outro" que nunca lhe é exterior, mas, ao contrário, interior e consubstancial, antes e fora do mundo.

O Evangelho de João não cessa de afirmar a interioridade recíproca do Filho e do Pai: "Como tu, Pai, tu es em mim e eu em ti" (Jo 17, 24; ver também Jo 17,$21 ; 10,38 ; 14,10)$. Graças à Encarnação na carne de um homem "vindo de Deus", isto é, o Messias ou o Cristo, a estrutura interna do processo da Vida absoluta se repete na relação entre o absoluto e o ser humano. A união que se opera é uma deificação. Segundo a intuição de Irineu, trata-se da restauração do ser humano na sua condição originária de ser criado por Deus à sua imagem, isto é, gerado na auto-geração da Vida absoluta no seu Verbo: no seu nascimento transcendental.

A unidade absoluta de todos os Si vivos não significa a aniquilação das individualidades, ao contrário, é constitutiva delas. Essa irredutibilidade de cada um motiva a extraordinária atenção do Cristo a cada um, no que cada 
um possui de único. É o que motiva também a rejeição de toda diferença no sentido de discriminação entre os Si transcendentais: "Nem grego nem judeu, nem senhor nem servo, nem homem nem mulher (Gal 3, 28)". "É assim que cada Si transcendental vivo existe no Verbo antes de existir consigo mesmo e, nesse Verbo, ele existe com o outro antes que o outro seja dado a si mesmo (ID., p. 356)". Michel Henry vê aqui uma das intuições mais extraordinárias do cristianismo.

No corpo místico, há sempre um elemento que edifica e um elemento que é edificado. O primeiro é a "cabeça" do corpo, o Cristo. "Na medida em que ele é a Encarnação real do Verbo, o Cristo edifica primeiro todo Si transcendental vivo na sua Ipseidade originária, que é a da Vida absoluta, e o junta a si mesmo (ID., p. 357)". Cada um entra assim no fluxo da consciência interna do tempo, que não é nem linear nem indeterminado, mas impressional e carnal, por obra da Arqui-passibilidade da Vida. Esse fluxo "está secretamente orientado na direção de uma agonia, da última passagem do último sofrimento do desespero para a irrupção de uma alegria sem limites, assim como atestado na Parusia dissimulada na madeira da Cruz (ID., p. 358)". Assim, o corpo místico do Cristo é acrescido indefinidamente por todos aqueles que são santificados na carne do Cristo, constituindo-se como "a pessoa comum da humanidade", e chamado doravante de "Novo Adão" (Cirilo de Alexandria). A esse corpo e a cada um dos seus membros é dado cumprir e acabar o que não estava ainda acabado no Cristo: "Preencho o que resto das aflições de Cristo, na minha carne, a favor do seu corpo, que é a igreja (Col 1, 24)". Aos membros do corpo, a todos aqueles que são em Cristo, será dada a Vida eterna, de modo que nesta vida que se tornou a vida deles, eles sejam salvos.

A nossa carne carrega em si o princípio da sua manifestação, diferente do aparecer do mundo. Ela é, no seu pathos, a Arqui-revelação da Vida, a Parusia do absoluto. "No fundo da sua Noite, nossa carne é Deus (ID., 373)", segundo a genial intuição de Mestre Eckhart. Assim, a Arquiinteligibilidade joanina, quando se manifesta na inocência da carne, no sofrimento e na alegria, no seu poder sem limites e até no desespero, na ebriedade infinita da vida e no Arqui-gozo do seu amor eterno em seu Verbo, quando o seu Espírito nos submerge, nos aparece como uma Arquignose, que é a gnose dos simples. 


\section{Visível e invisível: a Encarnação da Vida absoluta na pintura de Wassily Kandinsky.}

É uma experiência análoga à experiência da carne e da Encarnação que Michel Henry retrata no livro: "Voir l'invisible, sur Kandinsky", quando está à procura da essência da pintura, pelo estudo dos escritos teóricos do pintor.

Os maiores pintores apresentaram a sua arte como um modo de conhecimento metafísico, aquele que, atravessando a aparência sensível, nos faz descobrir o mistério das coisas, o segredo do universo. A pintura pode nos fornecer um conhecimento capaz de ir além da aparência exterior dos fenômenos para nos entregar a sua essência íntima. Não se trata do conhecimento "objetivo" perseguido pela ciência, que nunca alcançará o seu fim, um objeto ou uma coisa desprovida de interioridade. O conhecimento aberto pela arte é um conhecimento sem objeto. Seu meio ontológico é a vida, que se abraça a si mesma inteira sem nunca separar-se de si, sem colocar-se diante de si como um ob-jeto. O ponto de partida e o conteúdo da pintura é uma emoção, um modo mais intenso da vida. O conhecimento da arte desenvolve-se integralmente na vida, é o próprio movimento da vida. Longe de ser uma imitação, a arte expressa sempre formas elevadas da vida. Sua missão é de sustentar e levar ao paroxismo da vida a pulsão do Ser em nós, à qual ela pertence, até o ponto onde a vida se experimenta no seu próprio fundo, mergulhando na "impossível felicidade" que Kandinsky chama de "êxtase". Parece que estamos lendo aqui uma transposição da fenomenologia da vida exposta acima.

"Porque a verdade da arte é apenas uma transformação da vida do indivíduo, a experiência estética contrata com a ética um vínculo indissolúvel, é ela mesma uma ética, uma "prática", um modo de realização da vida (HENRY, 1988, p. 38-39).” Essa conexão interior da vida estética invisível

\footnotetext{
4 Wassily Kandinsky (1866-1944). Pintor russo, considerado como um dos "inventores" da pintura abstrata no decorrer dos anos 1910. Procura mostrar, além da aparência das coisas, o peso determinante das motivações interiores. Fundador e presidente de diversos grupos, entre outros "O cavaleiro azul" (Der blaue Reiter), um dos representantes do expressionismo alemão. Passa a priorizar as imagens surgidas do inconsciente, à procura da pintura "pura" ou "absoluta". Aos poucos, a abstração se torna a forma "necessária" para a expressão dos conteúdos que ele tem em mente. Autor de várias obras teóricas, em particular sobre "o espiritual na arte" e a questão da forma. Participou dos projetos do Bauhaus de Walter Gropius entre 1922 e 1933. Deixa a Alemanha em 1933 e se refugia em Paris, onde morre em 1944. Durante essa última fase, a sua pintura mostra um estranho universo de formas biológicas.
} 
com a vida ética, é o que Kandinsky chama o "espiritual”. O “espiritual” é a dimensão própria da arte, a vida invisível com a qual a arte se identifica. A liberação do "espiritual", essa realidade invisível que somos no fundo do nosso ser e que constitui o Ser verdadeiro - volta a ser o conhecimento metafísico que a arte assumia no passado. A arte chega a ser a única salvação possível em nossa sociedade dominada pela objetividade.

A obra considerada como este exterior, como este quadro que vemos, só pode tomar emprestado o seu conteúdo à subjetividade da vida na qual a realidade se concentra, inclusive a realidade da arte. Essa subjetividade viva, Kandinsky a chama alma e ele chama suas modalidades afetivas, suas emoções concretas de vibrações da alma. Sem vibração da alma, não pode haver obra. O Ser está atravessado por duas dimensões, que rasgam a sua unidade primitiva: o visível na luz do mundo como exterioridade; o invisível anterior ao surgimento do horizonte de exterioridade que constitui cada coisa como ob-jeto para nós, isto é, a vida que se experimenta a si mesma no seu pathos interior e imediato. Desde os Gregos, a pintura pertence ao campo do visível, do fenômeno, do que se mostra na luz do mundo. Mas, a noção de fenômeno sofrerá uma mutação decisiva quando, deixando de se submeter docilmente às injunções do visível, estará colocada em relação com a vida, com o invisível.

As duas maneiras de viver os fenômenos derivam de duas propriedades próprios dos mesmos: Exterior - Interior. É isso que percebemos constantemente na experiência do nosso próprio corpo e de seus dois modos de aparecer. Por um lado, vivo interiormente esse corpo, coincidindo com ele e com o exercício de cada um dos seus poderes: ver, ouvir, sentir, mover as mãos, sentir fome, sentir frio etc., de modo que eu sou esse ver (etc.), sem poder me diferenciar da sua subjetividade pura. Por outro lado, vivo exteriormente esse mesmo corpo: posso vê-lo, tocá-lo, me representa-lo como uma realidade exterior que faz parte do mundo. É a exterioridade que produz o fenômeno enquanto tal, que faz que ele se mostre. Mas a interioridade é também um modo do fenômeno se mostrar. É o invisível, que nunca se deixa ver num mundo nem ao modo de um mundo. O interior se revela ao modo da vida, a qual se sente a si mesma imediatamente, coincidindo em tudo consigo mesma. Isto é, a vida se realiza como um pathos, na afetividade.

Kandinsky explica a capacidade extraordinária da arte de pintar o invisível - nossas pulsões, nossos afetos, a nossa força - por meio de uma análise fenomenológica que, além de toda teoria, nos dá a ver, ou melhor, a 
sentir, nesta verdade e nesta certeza incontestável que é a experiência imediata que a vida tem de si mesma, a possibilidade, isto é, a "essência" da pintura. É que a pintura do visível ou do mundo aparece como subordinada a um modelo preexistente, como reprodução ou imitação fiel do modelo. Assim, a obra fica sempre em estado de inferioridade em relação com o modelo e perde toda significação criadora verdadeira.

Tudo muda quando a pintura não quer mais representar o mundo e seus objetos, quando deixa de ser a pintura do visível para pintar o invisível. O quadro e o que representa estão diante de nós, são "exteriores", são um fragmento do mundo, enquanto o conteúdo vivo é uma realidade interior, invisível. A pintura abstrata vai finalmente abolir essa dissociação entre um conteúdo interior e os meios exteriores. Já ficou claro que o conteúdo de toda pintura é o interior, a vida em si mesma invisível. Mas também "os meios pelos quais se trata de expressar este conteúdo invisível - as formas e as cores - são, eles mesmos, invisíveis, na sua realidade originária e mais própria (ID., p. 24)". A forma e todos os seus elementos libertam-se de toda relação de subordinação alheia à vida. Nasceu uma forma nova, "a forma puramente artística que pode conferir ao quadro a potência de uma vida independente e elevá-lo ao nível de sujeito espiritual" (ID., p. 47). Assim o conteúdo e os meios da pintura são ontologicamente homogêneos, pois eles constituem uma única realidade, uma única essência da pintura.

Segundo Henry, Kandinsky é o inventor da pintura abstrata, no ato de pintar e na reflexão teórica. Apesar do seu caráter revolucionário, a pintura abstrata nos leva de volta à fonte de toda pintura e só ela nos permite entender a possibilidade da pintura em geral, ao nos remeter ao seu fundamento sempre presente e ativo, à fonte eterna de toda criação. Kandinsky chama de abstrato o conteúdo que a pintura deve expressar, essa vida invisível que nós somos, e também os meios, quando são apreendidos na sua pureza.

O que significa "abstrato" na expressão: "pintura abstrata"? No sentido comum da palavra, uma coisa é dita abstrata quando é separada da realidade à qual pertence. Há abstração quando deixamos de considerar esta realidade conforme o conjunto das suas características, separando algumas para considera-la à parte: cor, forma etc. Afinal, só haveria uma realidade concreta: o mundo visível. Em geral, o que chamamos de "pintura abstrata" diz respeito a uma realidade abstrata do mundo, elaborada a partir dele, e constituindo o seu modo de expressão mais adequado. É o caso das composições picturais baseadas em formas geométricas. Estas são abstratas enquanto construídas a partir das formas sensíveis, por uma espécie de filtragem das mesmas. 
Elas não deixam, contudo, de fazer parte do mundo. Assim, a abstração do cubismo não deixa de pertencer ao processo figurativo e deve ser entendida como uma das suas modalidades de realização.

A abstração de Kandinsky não tem nada a ver com o tipo de abstração que caracteriza as diversas tentativas do começo do século XX: cubismo, orfismo, futurismo, surrealismo, construtivismo, cinetismo, conceitualismo etc. Tratava-se de voltar à percepção verdadeira, àquilo que se dá na experiência visual do mundo. Para Kandinsky, a abstração, o conteúdo abstrato é a vida invisível na sua incansável vinda a si mesma. É o contínuo jorramento interior da vida, sua essência eternamente viva que, ao mesmo tempo, fornece à pintura o seu conteúdo e impõe ao artista o seu projeto, o de expressar a profusão patética do Ser. "Abstrato" é o que existia antes do mundo e não precisa dele para ser: a vida que se abraça na noite da sua subjetividade radical, onde não há luz nem mundo. Nenhum caminho leva à vida, senão a própria vida, pois ela é ao mesmo tempo o fim e o caminho. Kandinsky queria apenas representar a sua emoção, um saber que nenhuma reflexão esclarece e que não é precedido por nenhuma história. É isso que constituía para ele o conteúdo de toda pintura possível: a profusão da vida nele, sua intensificação e sua exaltação. O invisível se torna anterior num domínio que era desde sempre o domínio do visível, dos sentidos. Cf. o quadro $A$ velha cidade, que queria pintar Moscou na melhor hora do dia, alguns momentos antes do pôr do sol (ID., p. 35-36). Evocar essa hora parecia para ele a maior das felicidades, providenciava uma alegria que o perturbava até o fundo da alma e que alcançava o êxtase.

$\mathrm{Na}$ percepção comum, temos a ver com os objetos. As cores e formas não são percebidas em si mesmas, mas apenas como signos do objeto, como simples meios ou instrumentos. Toda percepção é prático-utilitária no seu princípio. Assim, a aparência sensível encontra-se despossuída de si mesma em proveito do que ela indica. A pintura, ao contrário, é uma contra-percepção. Nela, a corrente de significados referenciais se interrompe abruptamente sob o olhar do artista. Cores e formas deixam de figurar o objeto e valem em si mesmas, tornaram-se formas picturais puras. Elimina-se o universo objetivo da percepção e liberam-se correlativamente as formas picturais. Já ao sair do tubo, as cores parecem viver em si e por si, autônomas e dotadas das qualidades necessárias a sua futura vida autônoma, dispostas a criar constantemente novas combinações, novas misturas e a criar uma infinidade de estranhos mundos novos. A pintura abstrata suscita a infinidade das formas possíveis, abrindo assim, fora do nosso mundo, um universo formal inteiramente novo. 


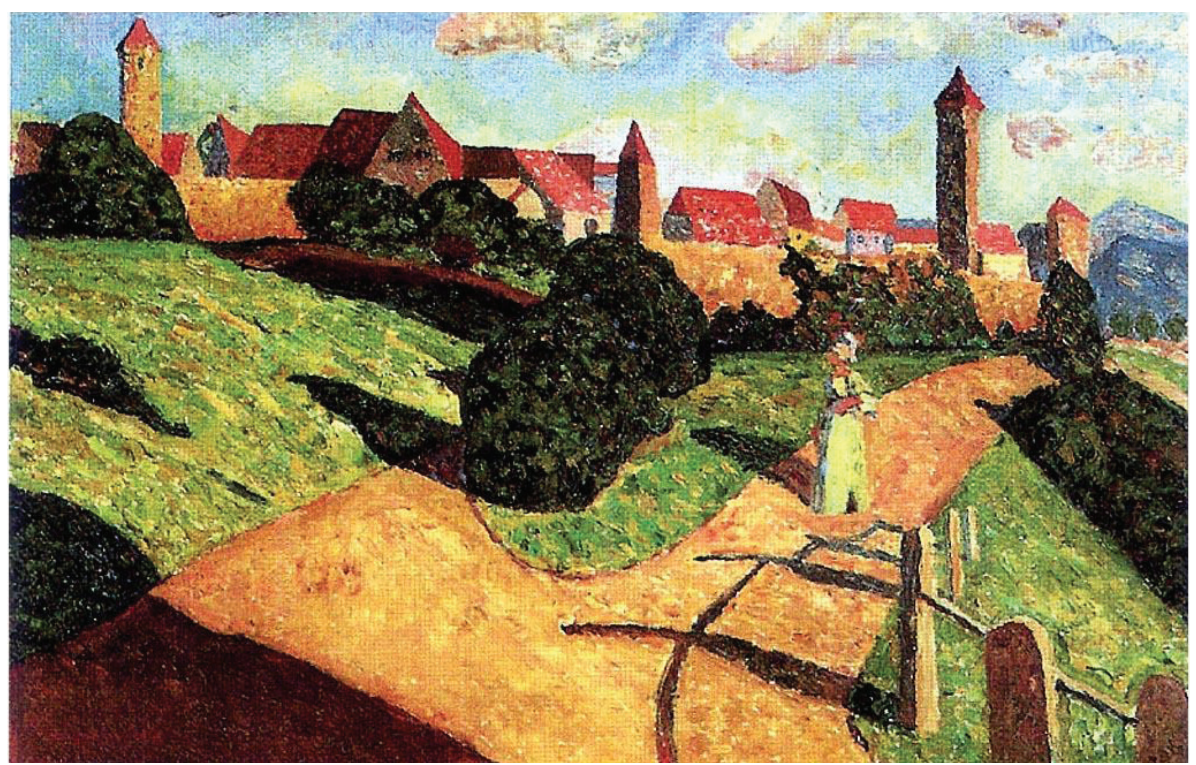

A velha cidade (1902) pt.wahooart.com Acesso 30/06/2020

A obra de arte procede da imaginação. Imaginar é colocar diante de nós outra coisa do que o que é, é colocar a vida diante de nós. A obra de arte não é mais imagem das coisas, cópia, reprodução, imagem do mundo como tal, como na visão grega. O produto da imaginação não é uma imagem e a arte não é um imaginário, pois a imaginação só pertence à vida. Ela é imanente e, como a vida, ela se experimenta a si mesma numa imediação nunca rompida, ela é um pathos, a plenitude de uma experiência. Ela não é mais, como em Kant, a faculdade de se representar as coisas na sua ausência, mas é o poder mágico de tornar as coisas reais, ela é criadora num sentido radical. O movimento da imaginação produz modalidades inéditas da vida, isto é, vibrações da alma.

É porque a vida nunca é para si mesma um objeto que pode e deve constituir o único conteúdo da arte e da pintura - conquanto esse conteúdo seja abstrato, invisível. A vida está presente na arte como o que sentimos em nós através das tonalidades e sonoridades das cores e das formas: o tema da obra, que é o seu pathos. O tema não é anterior nem posterior à obra, ele nunca se separa dela nem da sua pictorialidade pura, ele se confunde com ela, é o seu conteúdo real e invisível, seu conteúdo abstrato. A arte não representa nada: nem mundo, nem força, nem afeto, nem vida. 
A vida fornece à arte a sua única realidade concebível e o seu único conteúdo. A arte é um modo de vida no qual a vida está presente de maneira diferente da existência comum, ela está presente conforme a sua essência própria: experiência de si e crescimento de si, vir a si, tomar posse do próprio ser, ser afetado de um mais que si mesmo. E esse "mais" é um modo de gozar de si, é o próprio gozo. Por isso, a vida é um movimento: o eterno movimento da passagem do Sofrimento para a Alegria. A arte é a realização desse movimento eterno, é o próprio devir da vida, é a passividade radical da vida em relação a si mesma.

Toda pintura, assim como toda forma de arte (música, escultura, arquitetura, poesia, dança etc.), é abstrata. ${ }^{5}$ Trata-se de uma questão antropológica: o ser humano recebe da natureza do seu ser, da natureza do próprio Ser, a possibilidade de pintar que está inscrita nele. A pintura faz a economia da linguagem. Sensação pura, experiência pura, ela não precisa traduzir o conteúdo abstrato da nossa vida invisível, ela coincide com ela, é "o seu pathos, seu sofrimento, seu tédio, sua derrelicção ou sua alegria (ID., p. )". Ela elimina a mediação da referência objetiva e do que está vinculado a essa referência, como a linguagem, a representação e o pensamento. Ela questiona a cultura expressa no discurso, mítica ou conceitual, assentada no universo da representação, na relação simbólica ou cognitiva do sujeito e do objeto. Ela faz isso, por exemplo, quando substitui a toda forma mediata de expressão a ressonância afetiva imediata da cor em nós, isto é, a realidade originária da cor enquanto tal (ID., p. 127-128). Ela é popular no sentido em que ela reconduz cada ser humano ao que ele carrega de mais essencial em si: sua capacidade de sentir, de sofrer e de amar.

As análises dos elementos da forma pura por Kandinsky dizem respeito à cor, ao ponto, à linha, ao plano, ao formato do quadro, e à matéria sobre a qual foi pintado. São análises fenomenológicas que nos levam de volta à essência da coisa, isto é, o elemento pictural puro. Todo elemento se desdobra em exterior e interior, visível e invisível, segundo os dois modos do aparecer do Ser. O visível é a aparência exterior de cor, o traçado das linhas; o invisível é a tonalidade afetiva. Essa constitui a realidade ontológica desta cor ou desta forma, pois só há uma única realidade se manifestando a nós sob um duplo aspecto: o da tonalidade, de um lado; o da cor ou grafia, do outro

Para Kandinsky, há uma profunda afinidade entre a pintura e a música, de modo que ele fala muitas vezes da sonoridade das cores. Ele chegou a dar a suas obras picturais títulos de peças musicais, como composição, improvisação, invenção. 
lado. Interiormente, é a tensão viva intrínseca que constitui o elemento. A revelação interior do elemento, sua tonalidade afetiva constitui sozinha a sua realidade verdadeira, o que lhe confere o ser. "Nenhuma pintura, nenhum arte em geral seria possível, se a vida não tivesse prodigado a sua essência nesta dimensão do invisível que é a sua Morada (ID., p. 67)'.

Os caracteres essenciais, as formas picturais e gráficas pertencem à sensibilidade, isto é, à subjetividade absoluta e à sua Noite. Nas formas picturais puras aflora o conteúdo invisível da vida, a lenta subida do Desejo e de suas tribulações. As telas de Kandinsky, ao evocar um ambiente vazio de qualquer objeto identificável, como fora do mundo, "nos reconduzem ao lugar onde não há mais nem objeto nem mundo, pelo movimento que se apreende a si mesmo sem que nenhuma Distância o separe de si (ID., p. 77)". "A visão do invisível é o próprio invisível que toma consciência de si em nós, se exaltando a si mesmo e nos comunicando a sua alegria (ID., p. 79)".

Entre os elementos particulares, mencionarei as cores, as linhas e o plano originário. As cores são de natureza afetiva, invisível. Elas são sentidas na vida invisível e apenas nela. O se sentir a si mesma da vida na cor é o seu pathos. "A cor é, em si mesma, na substância fenomenológica de seu ser e na sua carne, como sensação e como subjetividade, a tonalidade afetiva, a sonoridade interior da qual é questão (ID., p. 125)". Toda cor possui um aspecto exterior e um aspecto interior. O primeiro é a extensão de cor na superfície das coisas. O segundo é a revelação invisível, "a sonoridade dessa cor, o sentimento do possível, de um mundo nascente para o branco, da morte para o preto, da calma para o verde, da profusão, isto é, da própria vida, para o vermelho, etc. (ID., p. 143)". As modalidades da vida subjetiva expressas pelas cores obedecem às leis da vida, especialmente à lei da "passagem", que é de ordem afetiva e expressa a natureza mais profunda da subjetividade, ou da oscilação perpétua entre o sofrimento e a alegria oscilação que constitui o fundo do nosso ser. As transformações mágicas das cores são a passagem de nossas tonalidades umas nas outras, são o devir da nossa vida.

Por sua vez, as formas lineares são capazes de expressar as forças subjetivas da vida. 'Elas não apenas 'representam', na sua variedade infinita, as forças e as pulsões de nossa vida, elas são idênticas a elas e se confundem com elas (ID., p. 91)". É que não há duas realidades, mas uma única força viva, que experimentamos sob a forma do pathos que se trata de expressar. O pathos de uma força que se afirma sem encontrar obstáculos é o lirismo. 
Quando duas forças entram em conflito, estamos no drama. "Assim o mundo das linhas, escreve Kandinsky, inclui todas as sonoridades expressivas, do lirismo frio ao drama ardente (HENRY, 1972, p. 76)". A força que produz uma linha goza de si mesma nesta produção, pois é esse gozo, o sentimento que a vida tem de si mesma que justifica o traçado.

O plano originário, que tem a forma de um retângulo, existe também como uma realidade autônoma, um ser vivo que possui uma "respiração". Assim, a atitude do pintor em frente dele deverá ser de respeito, de responsabilidade, como frente a tudo que é vivo. Já os grandes mestres do passado escolhiam o formato das obras em função do tema a ser expresso, que era algum grande pathos em consonância com sua vida e se confundindo com ela: tema da dor na paixão de Cristo, tema da vida e da morte, do tempo, da vaidade das coisas, da passagem das estações etc. Já que a pintura abstrata define a essência de toda pintura, é o conteúdo abstrato do plano originário, sua tonalidade subjetiva invisível que explica a escolha do formato em função do tema específico. No plano originário, a história de uma vida nos é contada, a história de uma força e de todas as resistências encontradas, passando do extremo do sofrimento ao extremo da alegria.

$\mathrm{Na}$ origem, toda arte é sagrada, a sua preocupação exclusiva é o sobrenatural, a vida do invisível. A vida é sagrada porque nos atravessa apesar do nosso querer. A passividade da vida em nós é a nossa subjetividade patética, o conteúdo invisível, abstrato, da arte eterna, da pintura. Daí a conexão presente em toda parte entre a arte e a religião. Desde o surgimento do cristianismo, não é mais o mundo que é representado, mas a vida invisível com suas tonalidades: força, alegria, amor, perdão, purificação, dom. Estamos em presença da afirmação da vida por ela mesma e contra a morte: fé, certeza, confiança em si; e seus contrários, em forma de afetos: medo, dúvida, tédio, inveja, orgulho, crueldade, derrelicção, luxúria, gula, sofrimento. Pensamos na representação dos pecados capitais por Jerônimo Bosch.

Contrariamente às aparências, todas as obras com conteúdo religioso da história da pintura ocidental são abstratas, pois nos dão a ver cenas que nunca ninguém presenciou, como o anjo parando a mão de Abraão segurando a faca, Moisés abrindo as águas do Mar Vermelho e submergindo Faraó e seu exército, o nascimento da Virgem Maria e sua Assunção, a fuga ao Egito, a conversão de Paulo, as línguas de fogo do Espírito. O que dizer de todas as Anunciações, Visitações, Adorações, Tentações, Mártires, Ressurreições? Todas essas obras primas giram em torno de um pequeno número de temas 
sempre repetidos, com uma extraordinária variedade e criatividade. É que a imaginação desloca essa pintura pretensamente figurativa para o campo da mais pura abstração. São as determinações invisíveis da subjetividade que funcionam desde o começo como princípios diretores da construção da obra. A motivação da escolha das formas é a sua sonoridade, a sua ressonância interior. As cores não são reais, mas escolhidas por elas mesmas, em função do seu valor próprio. Todas essas pinturas são abstratas. É o caso, por exemplo, do painel da Ressurreição no famoso retábulo de Issenheim, de Matthias Grünewald. Cores e movimentos são irreais, evocando apenas a auto-afirmação da vida na ebriedade e na certeza da sua força.

"Ver quer dizer, segundo os princípios da abstração, experimentar o pathos da cor que é vista, ser a realidade desse pathos, ser a Vida. O retábulo de Issenheim não representa a vida, ele nos dá de sentir a vida em nós, onde ela está adormecida desde sempre, enquanto arde, arde em si mesmo, arde em nós o Vermelho da Ressurreição (HENRY, 1988, p. 226)". O amarelo evoca força, energia, decisão, alegria, triunfo. Ele ressoa como uma fanfarra dominada pelo som forte, obstinado, inoportuno do trompete. "As formas [...] servem apenas para exaltar o jorramento irresistível, a irrupção triunfal da Vida (ID., p. 227)". "A arte é a ressurreição da vida eterna (ID., p. 244)", eis a última frase do livro. ${ }^{7}$

\section{Considerações finais}

Toda grande filosofia parte de uma intuição originária, de uma luz primordial que ilumina todo o caminho do pensamento. Para Michel Henry, é a experiência indemonstrável do pulsar da vida, é a vida que se experimenta a si mesma em nós, de modo imediato, como pathos: desejo, medo, dor, alegria, prazer, antes de tudo, sofrimento. Essa experiência acontece fora da exterioridade do mundo e do corpo objetivo mundano, no corpo-sujeito transcendental, isto é, na carne. É a apreensão imediata do Ser, na passividade primeira do afeto, na sensibilidade pura, num presente eterno, fora da linguagem, fora da intencionalidade, fora do pensamento. Por outro lado, a nossa vinda à vida na carne depende da Vinda originária da Vida a si mesma,

Cf. KANDINSKY, 1954, p. 130-131.

7 O pathos da vida que pulsa na pintura de Kandinsky é o mesmo que Aby Warburg encontrou na pintura renascentista, nas suas formas e nos seus movimentos. Uma comparação seria interessante. Ver os comentários de $O$ Nascimento de Vênus e de $A$ Primavera, de Sandro Botticelli, que ele apresenta no livro Histórias de fantasma para gente grande (WARBURG, 2015). 




Transverse line - iveteraffa.blogspot.com Acesso 30/06/2020

na Ipseidade do primeiro vivente, o Verbo de Deus. Assim, pela Encarnação do Verbo, a própria carne torna-se revelação de Deus. Ao tornar-se homem na carne do Cristo, Deus deifica o ser humano.

Do mesmo modo, na pintura abstrata de Kandinsky, a arte nos oferece a experiência do Ser, ao nos fazer experimentar diretamente a vida e o seu pathos, a sua passividade originária radical. Assim, a arte nos dá acesso ao conhecimento do mistério do universo. Trata-se de um conhecimento sem objeto, de uma impressão ou emoção, do próprio movimento da vida. Pela arte, a vida se experimenta em nós como "êxtase" fora do mundo. Como a vida na carne do ser humano ou do Cristo, a vida invisível em nós é um fazer, uma prática. Desse modo, a arte pode ser a única salvação possível numa sociedade dominada pela objetividade. A visão cristã da Encarnação está implicitamente presente na reflexão e na pintura de Kandinsky, sem precisar ser explicitada no discurso. A experiência da obra de arte - no artista e no espectador - é acesso ao pathos da vida - da vida humana e, de certo modo, da vida divina - pelo nosso corpo vivo - não objetivo - e todos os seus poderes: ver, ouvir, tocar, se movimentar etc. Pois a pintura é capaz de pintar o invisível: nossas pulsões, nossos afetos, a nossa força. 
Não só o conteúdo vivo, mas também os meios da pintura, como as cores e as formas, são uma realidade interior, invisível. Nesse sentido, eles são abstratos. Eles só dependem da vida. "Abstrato" é o começo absoluto, é a origem da vida, que se abraça na noite de sua subjetividade radical, e de todas as coisas. Ao eliminar o universo objetivo da percepção, a obra de arte procede da imaginação pura, imanente como a vida, se experimentando a si mesma numa imediação nunca rompida. Ela é um pathos, a plenitude de uma experiência e o eterno movimento da passagem do sofrimento para a alegria. Como a vida, a pintura é sem linguagem, sem representação, sem pensamento. A pintura é a morada invisível da vida.

Como a vida e como a rosa de Silesius, e graças ao desaparecimento da figura, a obra é sem porque, ela carrega em si o seu princípio último de inteligibilidade e justificação, enquanto expressão última da carne humana e divina. Como a vida, toda arte e toda pintura é sagrada, pois a passividade da vida em nós é o conteúdo invisível eterno de toda obra. Por isso, desde as origens do cristianismo, por mais figurativa que pareça, toda obra religiosa é abstrata, governada pelas determinações invisíveis da subjetividade, a afeição e a ação. A arte é a ressurreição da vida eterna.

Assim, Michel Henry entende a pintura de Kandinsky por meio da fenomenologia da vida, da carne e da Encarnação que ele desenvolveu no livro Incarnation. Deixarei para um possível aprofundamento futuro a questão de saber se uma experiência fenomenológica sem intencionalidade é possível, e a outra questão que Michel Henry deixou de certo modo em suspenso: a interpretação do dogma cristão da Encarnação é obra filosófica ou teológica? O meu objetivo foi relatar num ensaio o que entendi pela leitura dos textos de Michel Henry, sem recorrer aos inúmeros comentários já presentes na pesquisa acadêmica.

\section{Referências bibliográficas}

HENRY, M. C'est moi la vérité. Pour une philosophie du christianisme. Paris : Seuil, 1996. Trad. Port. Eu sou a verdade: por uma filosofia do cristianismo. São Paulo: É Realizações, 2015.

HENRY, M. L'Essence de la manifestation. Paris : PUF, 1963.

HENRY, M. Philosophie et Phénoménologie du corps. Paris : PUF, 1965.

HENRY, M. Incarnation. Une philosophie de la chair. Paris : Seuil, 2000. Trad. Port. Encarnação, Uma filosofia da carne. São Paulo: É Realizações, 2014. 
HENRY, M. Paroles du Christ. Paris : Seuil, 2002.

HENRY, M. Voir l'invisible. Sur Kandinsky. Paris : PUF, 2000.

HIGUET, E. Interpretação das imagens na teologia e nas ciências da religião. In: NOGUEIRA, P. A. S. Linguagens da religião. Desafios, métodos e conceitos centrais. São Paulo : Paulinas, 2012, p. 69-106

KANDINSKY, W. Du spirituel dans l'art et dans la peinture en particulier. Paris : Denoël, 1954. Trad. Port. Do espiritual na arte e na pintura em particular. São Paulo: Martins Fontes, 1990.

KANDINSKY, W. Point - ligne - action. Paris : Denoël, 1972.

TILLICH, P. Religious Dimensions of Contemporary Art. In : On Art and Architecture, New York: Crossroad, 1987, p. 171-187. Ed. John Dillenberger.

WARBURG, A. Histórias de fantasma para gente grande. Escritos, esboços e conferências. São Paulo: Companhia das Letras, 2015.

WUNENBURGER, J-J. Philosophie des images. Paris : PUF, 1997.

Submetido em: 30-6-2020

Aceito em: 4-8-2020 